\title{
Synthesis and photophysics of new pyridyl end-capped 3D- dithia[3.3]paracyclophane-based Janus tectons: surface-confined self-assembly of their model pedestal on HOPG
}

Received 00th January 20xx, Accepted 00th January 20xx

DOI: $10.1039 / \times 0 \times x 00000 x$

\section{Auffray, ${ }^{a}$ F. Charra, ${ }^{b}$ L. Sosa Vargas, ${ }^{a}$ F. Mathevet, ${ }^{a}$ A-J. Attias ${ }^{a}$ and D. Kreher ${ }^{a *}$}

Surface-confined supramolecular self-assembly is currently a promising strategy to create well-organised 2D-networks on conducting surfaces. However, using such substrates tends to quench any electronic properties of the adsorbed molecules. In this context, new pyridyl end-capped 3D-dithia[3.3]paracyclophane-based molecules were designed, as well as its model compound (pedestal), with the objective of self-assembling these tectons on any substrate. The synthesis of these new molecules was not straightforward and is consequently described into detail. Once the materials were successfully isolated, their optoelectronic properties were investigated to study potential non-covalent interactions: by $\mathrm{pH}$-dependant absorption and emission measurements, and by infra-red spectrometry. We evidenced that both ionic and coordination bonding are compatible with the molecules' design. Finally, preliminary scanning tunneling microscopy (STM) studies were performed to study the supramolecular self-assembly properties of the model lower-deck (pedestal) on highly oriented pyrollitic graphite (HOPG): we observed a quasi-square lattice of self-assembled 2D-networks which appear to form independently of the underlying HOPG lattice.

\section{Introduction}

In the field of nanotechnology, surface science plays a crucial role as most (nano-) devices eventually need to be supported on a surface. Therefore, controlling the adsorption on surface is utterly required, and commonly two contrasting strategies can be cited: top-down and bottom-up approaches. ${ }^{1}$ This latter consists in creating from a substrate a macro-scale object, starting from specifically designed molecular building blocks (tectons), through either chemisorption or physisorption process. In particular, the physisorption strategy is entirely based on the spontaneous organisation of molecules into stable and structurally well-defined networks on the surface, occurring by reversible supramolecular bonds between molecules and substrates, also called supramolecular self-assembly. On the one hand, the supramolecular bond between molecule and substrate depends on the nature of both, for example, the van der Waals interactions between alkyl chains and highly oriented pyrolytic graphite (HOPG). ${ }^{2}$ On the other hand, it can be tuned via the main interactions between molecules themselves. In this context, surfaceconfined self-assembly at the liquid/solid interface is considered nowadays as a promising approach for directly building lowdimensional (2D) supramolecular nanostructures on surfaces, under

\footnotetext{
Sorbonne Université, UPMC Univ Paris 06, Institut Parisien de Chimie Moléculaire, UMR CNRS 8232, 4 Place Jussieu, 75252 Paris Cedex 05, France.

b. Service de Physique de l'Etat Condensé, CEA CNRS Université ParisSaclay, CEA Saclay, F-91191 Gif-sur-Yvette Cedex, France.

Electronic Supplementary Information (ESI) available:

See DOI: $10.1039 / x 0 x \times 00000 x$
}

both dynamic and thermodynamic control. ${ }^{3}$ Several examples have already been developed, by exploiting various supramolecular interactions such as van der Waals interactions, ${ }^{4}$ ionic bonds, ${ }^{5}$ hydrogen bonds, ${ }^{6}$ halogen bonds ${ }^{7}$ or even coordination. ${ }^{8}$ But in view of practical applications, it is still challenging to obtain functional surfaces, in particular due to the fact that by using semi-conducting or conducting substrates, charge-transfer and hybridisation occurring between the molecules and the substrate might significantly alter the electronic properties of the adsorbed molecules. As a consequence, and to preserve the electronic properties, the molecule has to be decoupled (or "lifted") from the substrate. ${ }^{9}$ To overcome this issue, effective ways of decoupling have been studied by using multilayers of molecules, ${ }^{10}$ ultra-thin insulating layers onto the conducting surface ${ }^{11}$ or by chemically modifying the structure molecule with molecular landers. ${ }^{12}$

However, all these strategies do not allow to preserve simultaneously both the self-assembly and the electronic properties of the adsorbed molecules. Moreover, drastic conditions such as low temperature and high vacuum are required. To overcome this drawback, our group recently proposed a new molecular design strategy that will allow us to conserve the molecular electronic properties whilst maintaining a stable, supramolecular self-

assembled network. Our goal was to achieve a highly ordered, selfassembly on highly oriented pyrolytic graphite (HOPG) and graphene substrates at room temperature, by using the so-called Janus-like 3Dtecton design. ${ }^{13}$ This type of molecular architecture presents doublyfunctionalised building blocks where two opposite faces are linked 
by a rigid dithia[3,3]paracyclophane bridge. One face (pedestal) is responsible for guiding the $2 \mathrm{D}$ self-assembly whereas the other can be functionalised at will by any active moiety. The concept was proven successful, and the fluorescence of self-assembled molecular monolayers could be measured from perylene-functionalised Janus tectons on graphene, at ambient conditions. ${ }^{14}$ These Janus-tectons were initially developed with self-organising pedestals that were driven by van der Waals interactions between alkylated chains.

But such a design restricted its adsorption to only $\mathrm{sp}^{2}$-hybridised carbon substrates as HOPG or graphene. Therefore, a new design of cyclophane-based molecules is proposed using a new pedestal able to adsorb and self-organise on any substrate, by exploiting different supramolecular interactions. To achieve this goal, the pyridine moiety was chosen due to its well-known ability to form ionic bonds via a simple protonation, halogen or hydrogen bonding or coordination-type bonding with the corresponding additives. ${ }^{15}$

\section{Experimental}

\subsection{Materials and methods}

All solvents and reactants were purchased from commercial suppliers. The reactants were used without further purification. When necessary, the solvents were dried by using a MBraun solvent purification system (MB SPS-800). The organic compounds purifications performed by chromatography were either carried out by gravity column chromatography using silica gel (Si 60, 40-63 $\mu \mathrm{m}$, Merck) or by flash chromatography (Combiflash Companion) with the same type of silica. The nuclear magnetic resonance experiments were recorded at 300 or $600 \mathrm{MHz}$ (Bruker, BBFO probe for the 2Dexperiments). The proton and carbon chemical shifts $(\delta)$ are reported in ppm and are referenced to the residual solvent signal: chloroform $\left(\mathrm{CDCl}_{3}, 7.26\right.$, 77.16). Infra-red spectra were recorded with a ThermoFisher Nicolet iS10 FT-IR spectrometer. UV/Vis spectra were recorded with a Varian Cary WinUV spectrophotometer. The cells were in quartz with two faces (thickness: $1 \mathrm{~cm}$ ). Photoluminescence spectra were recorded with a Varian Cary Eclipse fluorescence spectrophotometer. STM images were acquired at room temperature with a homemade digital system. The fast scan axis was kept perpendicular to the sample slope. Images acquired simultaneously in both fast scan directions are systematically recorded and compared. All images are corrected for the drift of the instrument by combining two successive images with downward and upward slow-scan directions. The solvent was phenyloctane (Aldrich, 98\%). The substrate was HOPG (Goodfellow) and the tips were mechanically formed from a $250 \mathrm{~mm} \mathrm{Pt}-\mathrm{Ir}$ wire (Pt80/Ir20, Goodfellow). The monolayers were formed by drop casting a droplet (ca. $10 \mu \mathrm{L}$, in dichloromethane) of the solution immediately after cleaving the substrate. The samples were heated at $80^{\circ} \mathrm{C}$ for 10 minutes before immersing the STM junction in an additional droplet of phenyloctane (ca. $10 \mu \mathrm{L}$ ) and approaching the STM tip.

\subsection{Synthesis}

Synthesis of 1,4-Bis[(trimethylsilyl)ethynyl]-2,5-dimethylbenzene $1 .{ }^{16}$ In a Schlenk tube, 2,5-dibromo-p-xylene $(2 \mathrm{~g}, 7.6 \mathrm{mmol}$ ), $\mathrm{PdCl}_{2}\left(\mathrm{PPh}_{3}\right)_{2}(265 \mathrm{mg}, 0.4 \mathrm{mmol})$, copper(I) iodide (70mg, $\left.0.4 \mathrm{mmol}\right)$ and triethylamine $(40 \mathrm{~mL}, 300 \mathrm{mmol}$ ) were added and put undert an Argon atmosphere. Trimethylsilylacetylene $(3.5 \mathrm{~mL}, 24 \mathrm{mmol})$ wasadded, and the Schlenk tube was sealed. The mixture was stirred at $100^{\circ} \mathrm{C}$ for 8 hours. The solution was diluted with dichloromethane, washed with water and dried over magnesium sulfate. After evaporation in vacuo, the residue was purified by flash chromatography ( $\mathrm{SiO}_{2}$, petroleum ether) to afford 1 as a white powder in $91 \%$ yield. ${ }^{1} \mathrm{H}$ NMR $\left(300 \mathrm{MHz}, \mathrm{CDCl}_{3}\right) \delta 7.26(\mathrm{~s}, 2 \mathrm{H}), 2.34$ (s, 6H), 0.25 (s, $\left.18 \mathrm{H}) .{ }^{13} \mathrm{C} \mathrm{NMR} \mathrm{(300} \mathrm{MHz,} \mathrm{CDCl}_{3}\right) \delta 137.66,132.97$, $123.18,104.03,99.67,19.97,0.18$.

Synthesis of 1,4-Diethynyl-2,5-dimethylbenzene $2 .{ }^{17}$ To a solution of $1(415 \mathrm{mg}, 1.4 \mathrm{mmol})$ in methanol $(25 \mathrm{~mL})$,potassium fluoride (350 $\mathrm{mg}, 6.0 \mathrm{mmol}$ ) was added. The mixture was stirred overnight at room temperature and then evaporated in vacuo. The crude product was purified by flash chromatography $\left(\mathrm{SiO}_{2}\right.$, dichloromethane) to afford 2 as a light yellow powder in $96 \%$ yield. ${ }^{1} \mathrm{H}$ NMR (300 MHz, $\left.\mathrm{CDCl}_{3}\right)$ $\delta 7.26(\mathrm{~s}, 2 \mathrm{H}), 3.33(\mathrm{~s}, 2 \mathrm{H}), 2.34(\mathrm{~s}, 6 \mathrm{H}) .{ }^{13} \mathrm{C} \mathrm{NMR}\left(300 \mathrm{MHz}, \mathrm{CDCl}_{3}\right)$ $\delta 137.91,133.40,122.48,82.33,82.26,19.94$.

Synthesis of 1,4-Bis[(pyridyl)ethynyl]-2,5-dimethylbenzene P. ${ }^{18}$ In a Schlenk tube, compound 2 (200 mg, $1.3 \mathrm{mmol}$ ), p-bromopyridine hydrochloride (500 mg, $2.0 \mathrm{mmol}), \mathrm{Pd}\left(\mathrm{PPh}_{3}\right)_{2} \mathrm{Cl}_{2}(46 \mathrm{mg}, 0.07 \mathrm{mmol})$

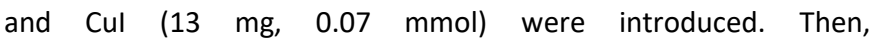
diisopropylamine $(15 \mathrm{~mL}, 107.0 \mathrm{mmol})$ was added and the mixture was stirred at RT, under an argon atmosphere for 8 hours. The resulting solution was diluted with dichloromethane, washed with water and dried over magnesium sulfate. After evaporation in vacuo, the residue was purified by flash chromatography $\left(\mathrm{SiO}_{2}\right.$, petroleum ether/ethyl acetate, 9:1) to afford $\mathbf{P}$ as a white powder in $85 \%$ yield. 1H NMR (300 MHz, $\left.\mathrm{CDCl}_{3}\right) \delta 8.63(\mathrm{~m}, 4 \mathrm{H}), 7.40(\mathrm{~m}, 6 \mathrm{H}), 2.49(\mathrm{~s}, 6 \mathrm{H})$. ${ }_{13} \mathrm{C} \mathrm{NMR}\left(300 \mathrm{MHz}, \mathrm{CDCl}_{3}\right) \delta 149.89,138.03,133.26,131.59,125.59$, 122.92, 92.75, 92.18, 20.12. HRMS: (EI) $\mathrm{m} / \mathrm{z}$ (\%) for C22H16N2; calcd 308.1313; found 308.1315. Anal. Calcd for C22H16N2 (MW 308.13): C, 85.69; H, 5.23; N, 9.08. Found: C, 85.75; H, 5.29; N, 8.92.

Synthesis of 1,4-dibromo-2,5-bis(bromomethyl)benzene $3 .{ }^{19}$ To a solution of 2,5-dibromo-p-xylene $(5 \mathrm{~g}, 19 \mathrm{mmol})$ in acetonitrile (75 $\mathrm{mL}) \operatorname{NBS}(7.1 \mathrm{~g}, 40 \mathrm{mmol})$ and AIBN $(160 \mathrm{mg}, 1 \mathrm{mmol})$ were added. The mixture was left stirring for 24 hours under reflux, after which the mixture was evaporated in vacuo and washed by hot methanol to afford 3 as a white powder in $60 \%$ yield. $\mathrm{Mp}=161^{\circ} \mathrm{C}$. ${ }^{1} \mathrm{H}$ NMR (300 $\left.\mathrm{MHz}, \mathrm{CDCl}_{3}\right) \delta 7.66(\mathrm{~s}, 2 \mathrm{H}), 4.51(\mathrm{~s}, 4 \mathrm{H}) .{ }^{13} \mathrm{C} \mathrm{NMR}\left(300 \mathrm{MHz}, \mathrm{CDCl}_{3}\right) \delta$ $139.14,135.50,123.43,31.62$.

Synthesis of 1,4-dibromo-2,5-dimethoxymethylbenzene 4. In a Schlenk tube compound $\mathbf{3}$ (1 g, $2.4 \mathrm{mmol})$, was added to degassed methanol $(20 \mathrm{~mL})$ and set to stir under an argon atmosphere. After stirring for 10 minutes, a freshly prepared sodium methoxide $(0.14 \mathrm{~g}$ of sodium in $20 \mathrm{~mL}$ of methanol) was added dropwise. Upon addition, the reaction was heated to $90^{\circ} \mathrm{C}$ and left stirring overnight. The resulting solution was then poured into water, extracted with dichloromethane and dried over magnesium sulfate. The 
dichloromethane was removed in vacuo to afford the title compound 4 as a white powder in quantitative yield. $\mathrm{Mp}=70^{\circ} \mathrm{C}$. ${ }^{1} \mathrm{H}$ NMR $(300$ $\left.\mathrm{MHz}, \mathrm{CDCl}_{3}\right) \delta 7.63(\mathrm{~s}, 2 \mathrm{H}), 4.47(\mathrm{~s}, 4 \mathrm{H}), 3.47(\mathrm{~s}, 6 \mathrm{H}) .{ }^{13} \mathrm{C}$ NMR $(300$ $\left.\mathrm{MHz}_{\mathrm{CDCl}}\right) \delta 138.50,112.33,121.30,73.23,58.89$.

Synthesis of 1,4-bis[(trimethylsilyl)ethynyl]-2,5-dimethoxymethyl benzene 5. In a Schlenk tube, compound 4 (1.9g, $6 \mathrm{mmol})$, $\mathrm{PdCl}_{2}\left(\mathrm{PPh}_{3}\right)_{2}(200 \mathrm{mg}, 0.3 \mathrm{mmol})$, Cul $(0.1 \mathrm{mg}, 0.3 \mathrm{mmol})$ and triethylamine (30 mL, $225 \mathrm{mmol}$ ) were mixed together under an argon atmosphere. Trimethylsilylacetylene $(2.7 \mathrm{~mL}, 19 \mathrm{mmol})$ was then added, the Schlenk tube was sealed and the mixture stirred at $100^{\circ} \mathrm{C}$ for 8 hours. The resulting solution was diluted with dichloromethane, washed with water and dried over magnesium sulfate. After evaporation in vacuo, the residue was purified by flash chromatography $\left(\mathrm{SiO}_{2}\right.$, petroleum ether) to afford the title compound 5 as a white powder in $84 \%$ yield. $\mathrm{Mp}=89{ }^{\circ} \mathrm{C}$. ${ }^{1} \mathrm{H}$ NMR $\left(300 \mathrm{MHz}, \mathrm{CDCl}_{3}\right) \delta 7.53(\mathrm{~s}, 2 \mathrm{H}), 4.57(\mathrm{~s}, 4 \mathrm{H}), 3.44(\mathrm{~s}, 6 \mathrm{H}), 0.24(\mathrm{~s}$, $18 \mathrm{H}) . .{ }^{13} \mathrm{C} \mathrm{NMR}\left(300 \mathrm{MHz}, \mathrm{CDCl}_{3}\right) \delta 139.43,121.23,122.01,100.96$, 72.11, 58.73, 0.07.

Synthesis of 1,4-diethynyl-2,5-bis(bromomethyl)benzene $6 .{ }^{20}$ In a Schlenk tube compound $5(0.45 \mathrm{~g}, 1.2 \mathrm{mmol})$ and dichloromethane $(10 \mathrm{~mL})$ were introduced and placed under an argon atmosphere. The mixture was then cooled to $0^{\circ} \mathrm{C}$ and then left to stir for 10 minutes, after which a solution of $\mathrm{BBr}_{3}(3.7 \mathrm{~mL}, 3.7 \mathrm{mmol})$ in dichloromethane $(10 \mathrm{~mL})$ was added dropwise through a dropping funnel. After stirring for 2 hours, the reaction mixture was poured into water and extracted with dichloromethane. The solution was dried over magnesium sulfate and evaporated in vacuo. The crude mixture obtained was then dissolved in methanol $(80 \mathrm{~mL})$ and potassium fluoride $(340 \mathrm{mg}, 6 \mathrm{mmol}$ ) was added. The solution was stirred overnight at room temperature and then poured onto water, extracted with dichloromethane and dried over magnesium sulfate. The solution was then evaporated in vacuo to afford the title compound 6 as a light-yellow powder in $47 \%$ yield. ${ }^{1} \mathrm{H} \mathrm{NMR}(300 \mathrm{MHz}$, $\left.\mathrm{CDCl}_{3}\right) \delta 7.58(\mathrm{~s}, 2 \mathrm{H}), 4.60(\mathrm{~s}, 4 \mathrm{H}), 3.51(\mathrm{~s}, 2 \mathrm{H}) .{ }^{13} \mathrm{C} \mathrm{NMR}(300 \mathrm{MHz}$, $\left.\mathrm{CDCl}_{3}\right) \delta 140.13,134.50,122.98,85.02,79.83,30.15$.

Synthesis of 4'-bromo-2,5-dimethyl-1,1'-biphenyl 7. p-bromophenyl boronic acid $(860 \mathrm{mg}, 4.30 \mathrm{mmol})$ and $\mathrm{Pd}\left(\mathrm{PPh}_{3}\right)_{2} \mathrm{Cl}_{2}(175 \mathrm{mg}$, $0.25 \mathrm{mmol}$ ) were added to a solution of 2 -iodo- $p$-xylene $(0.62 \mathrm{~mL}$, $4.30 \mathrm{mmol}$ ) in dioxane $(20 \mathrm{~mL})$ in an argon atmosphere. Then, $\mathrm{K}_{2} \mathrm{CO}_{3}$ $(2 \mathrm{~g}, 15.00 \mathrm{mmol}$ ) dissolved in water $(5 \mathrm{~mL})$ was added, and the mixture was heated at $110^{\circ} \mathrm{C}$ for 12 hours. The reaction was cooled to room temperature, and washed with water. The mixture was then extracted with dichloromethane, dried over magnesium sulfate and evaporated in vacuo. The crude was purified by chromatography $\left(\mathrm{SiO}_{2}\right.$, petroleum ether) to afford the title compound $\mathbf{7}$ as a colourless oil in $94 \%$ yield. ${ }^{1} \mathrm{H} \mathrm{NMR}\left(300 \mathrm{MHz}, \mathrm{CDCl}_{3}\right) \delta 7.61\left(\mathrm{~d},{ }^{3} \mathrm{~J}=8.5 \mathrm{~Hz}, 2 \mathrm{H}\right)$, $7.27(\mathrm{~d}, 3 \mathrm{~J}=8.5 \mathrm{~Hz}, 2 \mathrm{H}), 7.25(\mathrm{~d}, 3 \mathrm{~J}=8.0 \mathrm{~Hz}, 1 \mathrm{H}), 7.18(\mathrm{~d}, 3 \mathrm{~J}=8.0 \mathrm{~Hz}$, $1 \mathrm{H}), 7.12(\mathrm{~s}, 1 \mathrm{H}), 2.45(\mathrm{~s}, 3 \mathrm{H}), 2.31$ (s, 3H). ${ }^{13} \mathrm{C} \mathrm{NMR}\left(300 \mathrm{MHz}, \mathrm{CDCl}_{3}\right)$ $\delta 141.05,140.56,135.40,132.07,131.26,130.95,130.49,130.38$, $128.40,130.98,21.01,20.00$.

Synthesis of 1,4-bis(bromomethyl)benzene 8a. ${ }^{18}$ NBS (7.1 g, 40 $\mathrm{mmol}$ ) and AIBN (160 mg, $1 \mathrm{mmol}$ ) were added to a solution of $p$ - xylene $(2 \mathrm{~g}, 19 \mathrm{mmol})$ in acetonitrile $(60 \mathrm{~mL})$. After stirring for 16 hours under reflux, the mixture was evaporated in vacuo and purified by flash chromatography $\left(\mathrm{SiO}_{2}\right.$, petroleum ether: dichloromethane $1: 1)$ to afford $8 \mathrm{a}$ as a white powder in $87 \%$ yield. ${ }^{1} \mathrm{H} \mathrm{NMR}(300 \mathrm{MHz}$, $\left.\mathrm{CDCl}_{3}\right) \delta 7.37(\mathrm{~s}, 4 \mathrm{H}), 4.48(\mathrm{~s}, 4 \mathrm{H})$.

Synthesis of the 4'-bromo-2,5-bis(bromomethyl)-1,1'-biphenyl 8 b. To a solution of $7(1 \mathrm{~g}, 3.8 \mathrm{mmol})$ in acetonitrile $(100 \mathrm{~mL}) \mathrm{NBS}(1.4 \mathrm{~g}$, $8,0 \mathrm{mmol}$ ) and AIBN (60 mg, $0.4 \mathrm{mmol}$ ) were added. After stirring for 14 hours at $90^{\circ} \mathrm{C}$, the mixture was evaporated in vacuo and purified by flash chromatography ( $\mathrm{SiO}_{2}$, Petroleum ether) to afford the title compound $\mathbf{8 b}$ as a white powder in $90 \%$ yield. ${ }^{1} \mathrm{H}$ NMR $(300 \mathrm{MHz}$, $\left.\mathrm{CDCl}_{3}\right) \delta 7.60\left(\mathrm{~d},{ }^{3} \mathrm{~J}=8.5 \mathrm{~Hz}, 2 \mathrm{H}\right), 7.50\left(\mathrm{~d},{ }^{3} \mathrm{~J}=8.0 \mathrm{~Hz}, 1 \mathrm{H}\right), 7.41\left(\mathrm{dd},{ }^{3} \mathrm{~J}\right.$ $\left.=8.0 \mathrm{~Hz},{ }^{4} \mathrm{~J}=2.0 \mathrm{~Hz}, 1 \mathrm{H}\right), 7.32\left(\mathrm{~d},{ }^{3} \mathrm{~J}=8.5 \mathrm{~Hz}, 2 \mathrm{H}\right), 7.24\left(\mathrm{~d},{ }^{4} \mathrm{~J}=2.0 \mathrm{~Hz}\right.$, $1 \mathrm{H}), 4.49(\mathrm{~s}, 2 \mathrm{H}), 4.39(\mathrm{~s}, 2 \mathrm{H})$.

Synthesis of the 1,4-bis(mercaptomethyl)benzene 9a. ${ }^{21}$ To a solution of $8 \mathrm{a}(5 \mathrm{~g}, 18.9 \mathrm{mmol})$ in ethanol $(75 \mathrm{~mL})$ thiourea $(3.6 \mathrm{~g}$, $47.4 \mathrm{mmol}$ ) was added. The mixture was heated at $80^{\circ} \mathrm{C}$ for $3 \mathrm{~h}$ and then cool down to room temperature. After evaporation in vacuo, the residue was dissolved in water $(20 \mathrm{~mL})$. Sodium hydroxide was added $(2.25 \mathrm{~g}, 56.7 \mathrm{mmol})$ to the mixture, heated to $100{ }^{\circ} \mathrm{C}$ and left overnight. The solution was then extracted with diethylether and dried over magnesium sulfate. Evaporation in vacuo gave 9a as colourless crystals in $79 \%$ yield. ${ }^{1} \mathrm{H}$ NMR $\left(300 \mathrm{MHz}, \mathrm{CDCl}_{3}\right) \delta 7.27$ (s, $2 \mathrm{H}), 3.72(\mathrm{~d}, 4 \mathrm{H}), 1.75(\mathrm{t}, 2 \mathrm{H}) .{ }^{13} \mathrm{C} \mathrm{NMR}\left(300 \mathrm{MHz}, \mathrm{CDCl}_{3}\right) \delta 140.07$, $128.46,28.72$.

Synthesis of the 4'-bromo-2,5-bis(mercaptomethyl)-1,1'-biphenyl 9b. To a solution of $\mathbf{8 b}(900 \mathrm{mg}, 2.15 \mathrm{mmol})$ in ethanol $(50 \mathrm{~mL})$ thiourea ( $410 \mathrm{mg}, 5.35 \mathrm{mmol}$ ) was added. The mixture was heated at $80^{\circ} \mathrm{C}$ in a sealed Schlenk tube under an argon atmosphere for $3 \mathrm{~h}$ and then cooled down to room temperature. After evaporation in vacuo, the residue was dissolved in water $(50 \mathrm{~mL})$ and the solution was degassed. Potassium hydroxide was added $(1.2 \mathrm{~g}, 21.5 \mathrm{mmol})$ and the mixture was heated at $100{ }^{\circ} \mathrm{C}$ overnight in a sealed Schlenk tube. The solution was then extracted with diethylether and dried over magnesium sulfate. The evaporation in vacuo gave the title compound $\mathbf{9 b}$ as colourless crystals in $83 \%$ yield. ${ }^{1} \mathrm{H} \mathrm{NMR}(300 \mathrm{MHz}$, $\left.\mathrm{CDCl}_{3}\right) \delta 7.55\left(\mathrm{~d},{ }^{3} \mathrm{~J}=8.5 \mathrm{~Hz}, 2 \mathrm{H}\right), 7.37\left(\mathrm{~d},{ }^{3} \mathrm{~J}=8.0 \mathrm{~Hz}, 1 \mathrm{H}\right), 7.29\left(\mathrm{dd},{ }^{3} \mathrm{~J}\right.$ $\left.=8.0 \mathrm{~Hz},{ }^{4} \mathrm{~J}=2.0 \mathrm{~Hz}, 1 \mathrm{H}\right), 7.32\left(\mathrm{~d},{ }^{3} \mathrm{~J}=8.5 \mathrm{~Hz}, 2 \mathrm{H}\right), 7.13\left(\mathrm{~d},{ }^{4} \mathrm{~J}=2.0 \mathrm{~Hz}\right.$, $1 \mathrm{H}), 3.72\left(\mathrm{~d},{ }^{3} \mathrm{~J}=7.5 \mathrm{~Hz}, 2 \mathrm{H}\right), 3.62\left(\mathrm{~d},{ }^{3} \mathrm{~J}=7.5 \mathrm{~Hz}, 2 \mathrm{H}\right), 1.77\left(\mathrm{~d},{ }^{3} \mathrm{~J}=7.5\right.$ $\mathrm{Hz}, 1 \mathrm{H}), 1.66(\mathrm{~d}, 3 \mathrm{~J}=7.5 \mathrm{~Hz}, 1 \mathrm{H})$.

Synthesis of the 5,8-diethynyl-2,11-dithia[3.3]paracyclophane 10a. To a solution of potassium hydroxide $(100 \mathrm{mg}, 1.8 \mathrm{mmol}$ ) in methanol $(350 \mathrm{~mL})$, a mixture of $6(400 \mathrm{mg}, 1.3 \mathrm{mmol})$ and $9 a(200 \mathrm{mg}, 1.3$ $\mathrm{mmol})$ in dichloromethane $(50 \mathrm{~mL})$ were added dropwise using a syringe pump ( $4 \mathrm{~mL} / \mathrm{h})$, simultaneously with another solution of potassium hydroxide $(200 \mathrm{mg}, 3.6 \mathrm{mmol})$ in methanol $(50 \mathrm{~mL})$. At the end of the addition, the mixture was evaporated in vacuo. The residue was then dissolved in dichloromethane, washed with water, dried over magnesium sulfate and evaporated again in vacuo. The crude was purified by column chromatography $\left(\mathrm{SiO}_{2}\right.$, petroleum ether: dichloromethane 1:1) to afford the title compound 10a as a white powder in $43 \%$ yield. ${ }^{1} \mathrm{H} N M R\left(300 \mathrm{MHz}, \mathrm{CDCl}_{3}\right) \delta 7.14(\mathrm{~s}, 2 \mathrm{H})$, 
$7.06\left(\mathrm{~d},{ }^{3} \mathrm{~J}=8 \mathrm{~Hz}, 2 \mathrm{H}\right), 7.02\left(\mathrm{~d},{ }^{3} \mathrm{~J}=8 \mathrm{~Hz}, 2 \mathrm{H}\right), 4.30\left(\mathrm{~d},{ }^{3} \mathrm{~J}=15 \mathrm{~Hz}, 2 \mathrm{H}\right)$, $3.87(d, 3 \mathrm{~J}=15 \mathrm{~Hz}, 2 \mathrm{H}), 3.78(\mathrm{~d}, 3 \mathrm{~J}=15 \mathrm{~Hz}, 2 \mathrm{H}), 3.59(\mathrm{~d}, 3 \mathrm{~J}=15 \mathrm{~Hz}$, $2 \mathrm{H}), 3.43(\mathrm{~s}, 2 \mathrm{H})$.

Synthesis of the 5,8-diethynyl-13-(p-bromophenyl)-2,11-dithia[3.3] paracyclophane $10 \mathrm{~b}$. To a solution of potassium hydroxide $(100 \mathrm{mg}$, $1.8 \mathrm{mmol})$ in methanol $(600 \mathrm{~mL})$, a solution of $6(420 \mathrm{mg}, 0.9 \mathrm{mmol})$ and $9 \mathrm{~b}(300 \mathrm{mg}, 0.9 \mathrm{mmol})$ in dichloromethane $(50 \mathrm{~mL})$ were added dropwise using a syringe pump $(3.5 \mathrm{~mL} / \mathrm{h})$, simultaneously with another solution of potassium hydroxide $(200 \mathrm{mg}, 3.7 \mathrm{mmol})$ in methanol $(50 \mathrm{~mL})$. After addition was completed, the mixture was acidified with dilute $\mathrm{H}_{2} \mathrm{SO}_{4}$, extracted with dichloromethane, washed with water, dried over magnesium sulfate and evaporated in vacuo. The crude was purified by flash chromatography $\left(\mathrm{SiO}_{2}\right.$, petroleum ether: dichloromethane using a gradient from 1:0 to 1:1) to afford the title compound $10 \mathrm{~b}$ as a white powder with a yield of $60 \% .{ }^{1} \mathrm{H}$ NMR (300 MHz, $\left.\mathrm{CDCl}_{3}\right)$ 8 7.63-7.00 (m, 18H), 4.45-3.46 (m, 16H+4H).

Synthesis of the 5,8-bis[(pyridyl)ethynyl]-2,11-dithia[3.3]para cyclophane C. In a Schlenk tube, 10a (150 mg, $0.5 \mathrm{mmol})$, iodopyridine (480 mg, $2.4 \mathrm{mmol}), \mathrm{Pd}\left(\mathrm{PPh}_{3}\right)_{2} \mathrm{Cl}_{2}(35 \mathrm{mg}, 0.05 \mathrm{mmol})$ and poper(I) iodide (10 $\mathrm{mg}, 0.05 \mathrm{mmol})$ were added under an argon atmosphere. Then, diisopropylamine $(1.5 \mathrm{~mL}, 10.0 \mathrm{mmol})$ was added and the mixture was stirred for 20 hours at $20^{\circ} \mathrm{C}$. The solution was diluted with dichloromethane, washed with water and dried over magnesium sulfate. After evaporation in vacuo, the residue was purified by flash chromatography $\left(\mathrm{SiO}_{2}\right.$, petroleum ether: ethyl acetate, with a gradient 9:1 to 1:1) to afford the title compound $\mathbf{C}$ as a yellow powder in $44 \%$ yield. ${ }^{1} \mathrm{H} \mathrm{NMR}\left(300 \mathrm{MHz}, \mathrm{CDCl}_{3}\right) \delta 8.69(\mathrm{~s}$, $4 \mathrm{H}), 7.49\left(\mathrm{~d},{ }^{3} \mathrm{~J}=5.5 \mathrm{~Hz}, 4 \mathrm{H}\right), 7.22(\mathrm{~s}, 2 \mathrm{H}), 7.08\left(\mathrm{~d},{ }^{3} \mathrm{~J}=8 \mathrm{~Hz}, 2 \mathrm{H}\right), 7.05$ $\left(d,{ }^{3} \mathrm{~J}=8 \mathrm{~Hz}, 2 \mathrm{H}\right), 4.32\left(\mathrm{~d},{ }^{3} \mathrm{~J}=15 \mathrm{~Hz}, 2 \mathrm{H}\right), 3.90\left(\mathrm{~d},{ }^{3} \mathrm{~J}=15 \mathrm{~Hz}, 2 \mathrm{H}\right), 3.85$ (d, $3 \mathrm{~J}=15 \mathrm{~Hz}, 2 \mathrm{H}$ ), 3.72 (d, $3 \mathrm{~J}=15 \mathrm{~Hz}, 2 \mathrm{H}$ ). HRMS: (EI) $\mathrm{m} / \mathrm{z}$ (\%) for $\mathrm{C}_{30} \mathrm{H}_{22} \mathrm{~N}_{2} \mathrm{~S}_{2}$; calcd 474.1224; found 474.1224.

Synthesis of the 5,8-bis[(pyridyl)ethynyl]-13-(p-bromophenyl)2,11-dithia[3.3] paracyclophane JT. In a Schlenk tube, $10 \mathrm{~b}(170 \mathrm{mg}$, $0.36 \mathrm{mmol})$, iodopyridine $(370 \mathrm{mg}, 1.8 \mathrm{mmol}), \mathrm{Pd}\left(\mathrm{PPh}_{3}\right)_{2} \mathrm{Cl}_{2}(30 \mathrm{mg}$, $0.04 \mathrm{mmol}$ ) and copper iodide $(8 \mathrm{mg}, 0.04 \mathrm{mmol})$ were introduced under an argon atmosphere. Diisopropylamine $(1,5 \mathrm{~mL}, 10.0 \mathrm{mmol})$ was then added and the mixture was stirred for 24 hours at $20^{\circ} \mathrm{C}$. The solution was diluted with dichloromethane, washed with water and dried over magnesium sulfate. After evaporation in vacuo, the residue was purified by flash chromatography $\left(\mathrm{SiO}_{2}\right.$, petroleum ether: ethyl acetate, 9:1 to 1:1) to afford the title compound JT as a yellow powder in $84 \%$ yield. ${ }^{1} \mathrm{H} \mathrm{NMR}\left(300 \mathrm{MHz}, \mathrm{CDCl}_{3}\right) \delta 8.78-8.65$ (m, 8H), 7.61-7.06 (m, 26H), 4.45-3.46 (m, 16H). HRMS: (EI) m/z (\%) for $\mathrm{C}_{36} \mathrm{H}_{25} \mathrm{~N}_{2} \mathrm{~S}_{2}$; calcd 628.0643; found 628.0642 .

\section{Results and discussion}

In this paper, three bis(pyridyl)acetylene derivatives were synthesized (scheme 1): the planar pedestal $\mathbf{P}$ (for reference), the pedestal incorporating a cyclophane $\mathbf{C}$ (to check the influence of the cyclophane incorporation) and finally a functionalisable Janus tecton JT (where any active component could potentially be grafted).
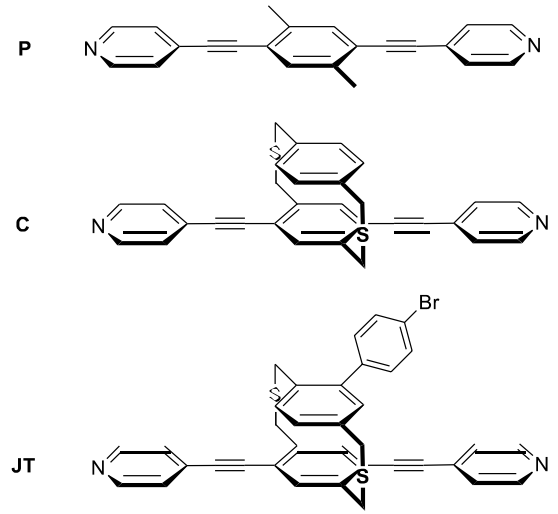

Scheme 1: Bis(pyridyl)acetylene-based target molecules

\subsection{Synthesis}

The molecule $\mathbf{P}$ was synthesised from the 2,5-dibromo- $p$-xylene via a Sonogashira cross-coupling reaction with trimethylsilylacetylene (TMSA), followed by the deprotection of the trimethylsilyl groups with potassium fluoride and finally by a second Sonogashira coupling with an overall yield of $70 \%$ (scheme 2 ).

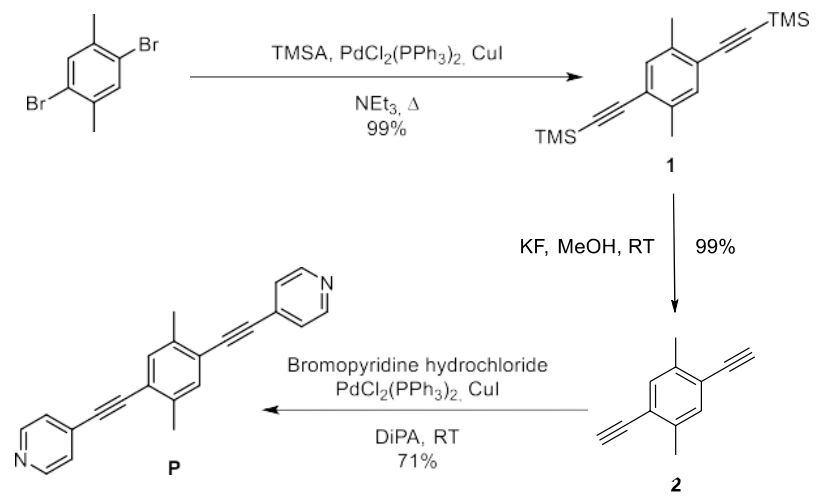

Scheme 2: Synthesis of $\mathbf{P}$

The syntheses of the cyclophane derivatives $\mathbf{C}$ and $\mathbf{J T}$ were not as simple and therefore several retrosynthetic routes were pursued in order to finally obtain the desired compounds (scheme 3). A total of four approaches were investigated with only route number four resulting successful (scheme 4).

Following route 4, 1,4-dibromo-p-xylene was brominated with NBS, following the Wohl and Ziegler radical pathway where AIBN is the radical initiator. ${ }^{16}$ The two bromomethyl groups of $\mathbf{3}$ were then protected by methoxy units (4) in order to perform a Sonogashira coupling with TMSA and give intermediate $\mathbf{5}$. After deprotection of both methoxy and trimethylsilyl groups using boron tribromide and potassium fluoride, respectively; the resulting compound 6 and either 1,4-bis(mercaptomethyl)benzene or 1,4-bis(mercaptomethyl) -2-( $p$-bromophenyl)-benzene were solubilised in dichloromethane and slowly added to a highly diluted solution of potassium hydroxide in methanol, to afford the cyclophane derivatives.

Finally, a last Sonogashira coupling with iodopyridine enabled us to recover the final products $\mathrm{C}$ and JT with an overall yield of $8 \%$ and $10 \%$, respectively. 


\section{NJC}

\section{ARTICLE}

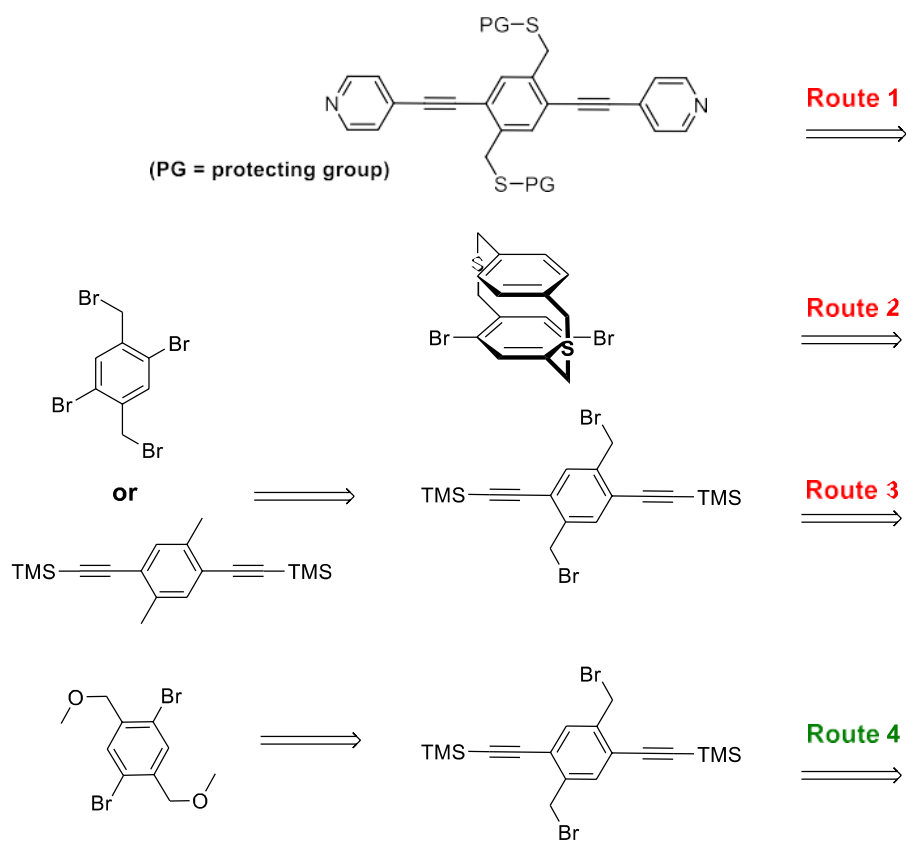

Scheme 3: Retrosynthetic routes attempted to reach target compound C<smiles>Cc1cc(Br)c(C)cc1Br</smiles>

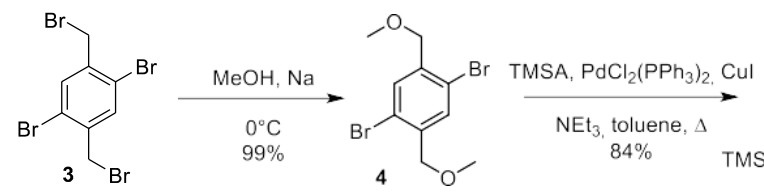<smiles>COCc1cc(C#CC#N)c(COC)cc1C#C[Na]</smiles>

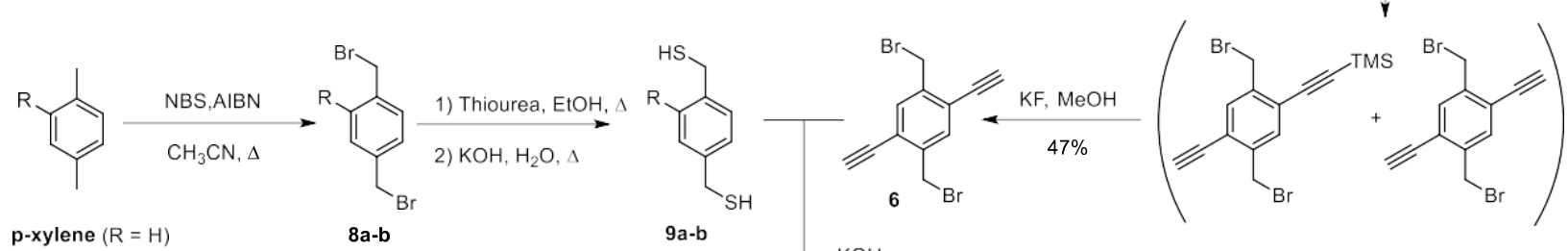

p-xylene $(\mathrm{R}=\mathrm{H})$

$7(\mathrm{R}=\mathrm{PhBr})$

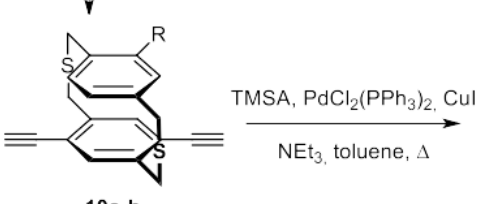

$$
\text { 10a-b }
$$

a : $R=H \quad(81 \%)$

$\mathrm{b}: \mathrm{PhBr}(60 \%)$

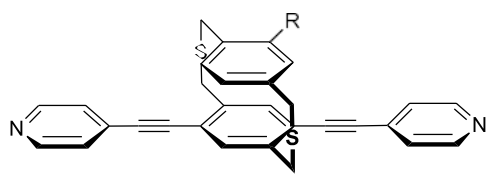

C : $\mathrm{R}=\mathrm{H}(44 \%)$ JT : $\mathrm{PhBr} \quad(84 \%)$

Scheme 4: Synthesis of C and JT 


\section{NJC}

\section{ARTICLE}

It is important to note as well that the Janus tecton JT was obtain as a mixture of two structural isomers, staggered and eclipsed, which could not be separated by chromatography.

\subsection{Nuclear Magnetic Resonance}

All intermediates and final compounds were first studied by NMR to confirm their chemical structures, before confirming their purity by elemental analysis or high resolution mass spectrometry. As an example, the ${ }^{1} \mathrm{H}$ NMR spectrum of $\mathbf{C}$ in deuterated chloroform is depicted in Figure 1.

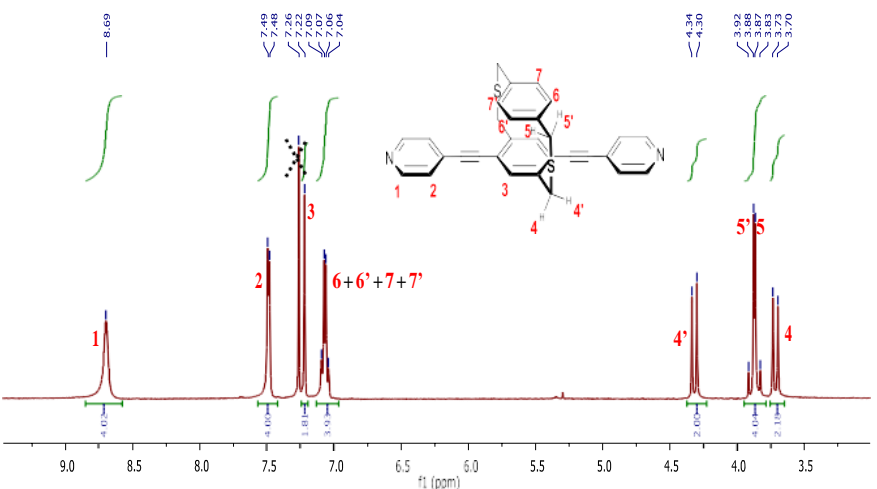

Figure 1: $300 \mathrm{MHz}{ }^{1} \mathrm{H}$ NMR of $\mathrm{C}$ in deuterated chloroform

The attribution of the aromatic part of this spectrum was made easy

by the previous study of $\mathbf{P}$ pedestal's NMR spectrum. Thus, the pyridine's protons 1 and 2 respectively correspond to the wide singlet at $8.69 \mathrm{ppm}$ and to the doublet at $7.48 \mathrm{ppm}$, both integrating for four protons. Then the protons 3 borne by the lower deck of the cyclophane are represented by a peak at $7.22 \mathrm{ppm}$, integrating for 2 . Finally, 6, 6', 7 and 7' are attributed to the close pair of doublet with a chemical shift of $7.06 \mathrm{ppm}$ integrating for 4 protons. These signals are undergoing a "roof-top effect" which indicates the second order coupling occurring between 6 and $6^{\prime}$, and between 7 and $7^{\prime}$. This slight coupling might occur because in each pair, one is located above the alkyne ( 6 and $7^{\prime}$ ) and the other above a simple proton ( $6^{\prime}$ and 7 ) As a consequence, the deshielding of the alkyne would slightly affect one of each pair, making them lightly different. A representation of the deshielding area of the alkyne is represented in Figure 2 .

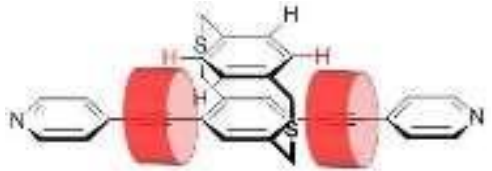

Figure 2: Deshielding effect of the alkyne unit in C
The attribution of the second part of the spectrum, concerning the $\mathrm{CH}_{2}$ protons of the cyclophane-bridge, is entirely based on second order couplings. Four doublets with a roof-top shape can be observed at the chemical shifts of $4.32,3.90,3.85$ and $3.70 \mathrm{ppm}$, integrating for 2 protons each. The protons $4^{\prime}$ and $5^{\prime}$ should thus be deshielded compared to their homologues 4 and 5 . However, since $4^{\prime}$ is closer to the alkyne than $5^{\prime}$, the effect would be enhanced. As a consequence, 5 and $5^{\prime}$ are respectively attributed to the pair of doublets located at 3.85 and $3.90 \mathrm{ppm}, 5^{\prime}$ being slightly more deshielded than 5 . The protons 4 are the more shielded of all, and correspond to the doublet at $3.70 \mathrm{ppm}$. Finally $4^{\prime}$, the most deshielded of all, is located at $4.32 \mathrm{ppm}$.

\subsection{Photophysics}

The absorption and emission spectra of both molecules $\mathbf{P}$ and $\mathbf{C}$ were measured in dichloromethane, as depicted in the Figure 3.

a)

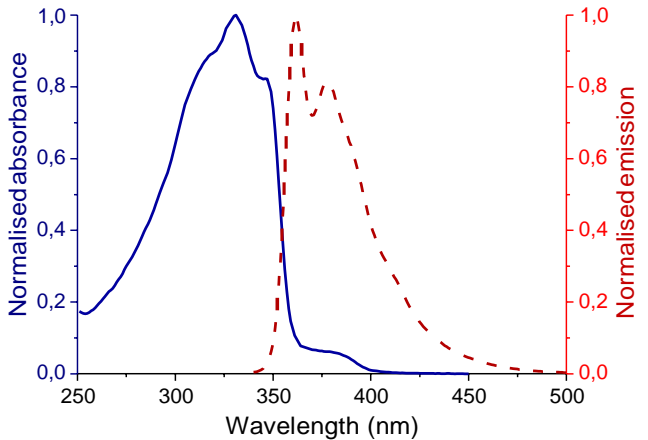

b)

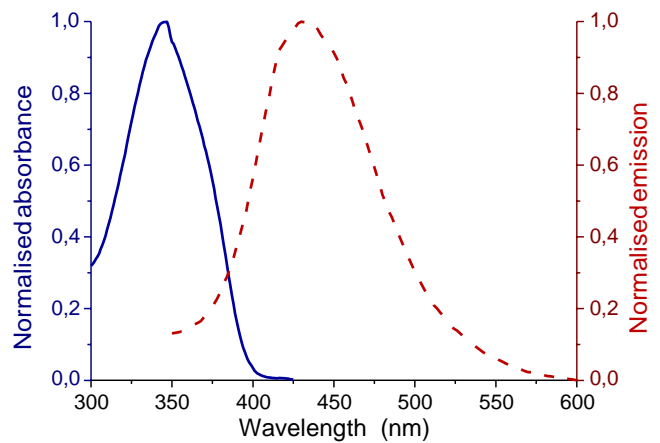

Figure 3: Absorption and emission spectra of $\mathbf{P}(\mathrm{a})$ and $\mathbf{C}(\mathrm{b})$ in dichloromethane

On the one hand, the absorption spectrum of $\mathbf{P}$ presented four transition bands at $318,331,347$ and $380 \mathrm{~nm}$, the band at $\lambda_{\max }=331$ $\mathrm{nm}$ being used to estimate the extinction coefficient $(\varepsilon)$, which was calculated at $35500 \mathrm{Lmol}^{-1} \mathrm{~cm}^{-1}$. The emission spectrum showed 
fluorescence in the blue region with a $\lambda_{\max }$ at $362 \mathrm{~nm}$, giving a Stokes shift value of $31 \mathrm{~nm}\left(1100 \mathrm{~cm}^{-1}\right)$. On the other hand, molecule $\mathbf{C}$ presented one single absorption band at $\lambda_{\max }=345 \mathrm{~nm}$. The fluorescence was redshifted from $P$, emitting at $\lambda_{\max }=434 \mathrm{~nm}$ with a new Stokes shift of $89 \mathrm{~nm}\left(5900 \mathrm{~cm}^{-1}\right)$, indicating a higher degree or reorganisation of the derivative $\mathbf{C}^{\prime}$ 's excited state in comparison with that of pedestal $\mathbf{P}$.

In addition, as pyridine units are commonly used as a Lewis base in organic reactions, a $\mathrm{pH}$-dependent study was therefore carried out by successive additions of trifluoroacetic acid (TFA) to a solution of $\mathbf{P}$ (respectively $\mathbf{C}, \mathbf{J T}$ ) in dichloromethane, each addition corresponding to 0.1 equivalents of TFA in the quartz cell. We will illustrate the results with focusing on $\mathbf{P}$ (Figure 4 ), as $\mathbf{C}$ and $\mathbf{J T}$ compounds behave in a similar way.

As reported, the addition of acid in the solution drastically increased the absorption band intensity at $380 \mathrm{~nm}$ and also reduced the two bands at 318 and $331 \mathrm{~nm}$ with an isobestic point located at $350 \mathrm{~nm}$. In addition, with a large excess of acid a slight blueshift of the maxima from 380 to $360 \mathrm{~nm}$ was observed, this hypsochromic shift being attributed to the second protonation.

a)

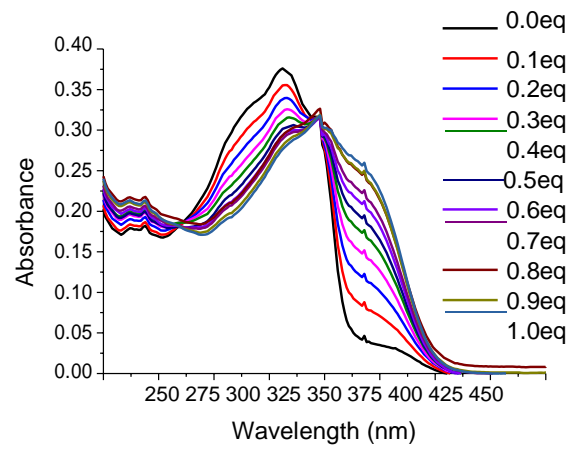

b)

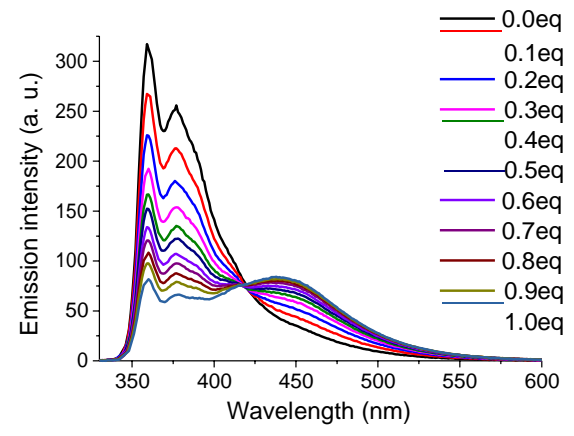

Figure 4: Absorption (a) and emission (b) spectra of $\mathbf{P}$ acidified with TFA

Moreover, the addition of acid quenched the emission of the neutral pedestal at both wavelengths 362 and $378 \mathrm{~nm}$ in favour of a new redshifted band at $\lambda=439 \mathrm{~nm}$ corresponding to the molecule monoprotonated. In this case, the isobestic point was located at $\lambda=419$ $\mathrm{nm}$. In accordance with the study on the absorption, a bisprotonated specie with a slight blue shift of the maxima of emission from 439 to $427 \mathrm{~nm}$ could be observed with a large excess of TFA. To sum up, the protonation of the pyridine units have a strong impact on the optical properties of $\mathbf{P}, \mathbf{C}$ and $\mathbf{J T}$.

\subsection{Supramolecular interactions studies on bulk}

Therefore, one of the aim of this work being to create self-assemblies based on the co-adsorption of $\mathbf{P}$ (respectively $\mathbf{C}, \mathbf{J T}$ ) with different additives, preliminary studies on bulk materials were performed, all three expected supramolecular entities being represented in Figure 5 along with the predicted supramolecular bonds with the pedestal

P.

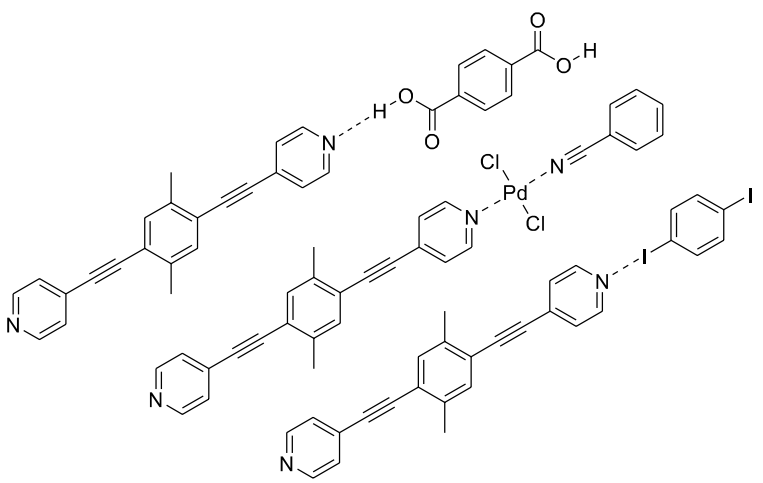

Figure 5: Expected supramolecular bonds between the pedestal $\mathbf{P}$ (respectively $\mathbf{C}, \mathbf{J T}$ ) and a) terephtalic acid TPA ( $\mathrm{H}$-bond), b) bis(benzonitrile) $\mathrm{PdCl}_{2} \mathrm{Pd}^{\prime \prime}$ (coordination bond) and c) 1,4-diiodobenzene IPhl (X-bond)

As evidenced by the protonation studies, the formation of ionic bonds by $\mathbf{P}$ (respectively $\mathbf{C}, \mathbf{J T}$ ) could be monitored by changes in the absorption and emission spectra after adding acid in the solution. But common characterisation to measure the strength of other supramolecular bonds such as coordination, hydrogen and halogen bonding by NMR being unsuccessfull due to poor solubility, additional infrared studies were performed.

To do so, as an example, different supramolecular entities were prepared in solution by simply mixing $\mathbf{P}$ with bis(benzonitrile)palladium(II) for coordination (P-Pd"), terephtalic acid for hydrogen bond (P-TPA) and finally 1,4-diiodobenzene for halogen bond (PIPhI). The infra-red spectra were recorded on bulk after evaporation or filtration of the supramolecular complexes (see Figure S29 in SI). Note that the specific $\mathrm{C}-\mathrm{N}$ stretching band within the pyridine units is centered at $1591 \mathrm{~cm}^{-1}$ for $\mathbf{P}$ (see Figure 6), this shift being known to depend on the different supramolecular assemblies present, as described for different coordination complexes in the literature. ${ }^{22}$

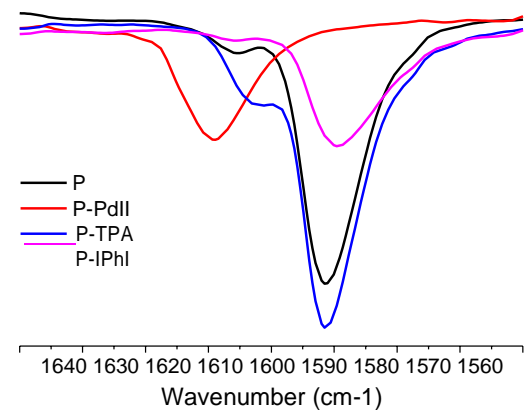

Figure 6: Infra-red spectra of the different supramolecular entities; focus on the $\mathrm{C}-\mathrm{N}$ stretching bands

The stretching bond value of the $\mathrm{C}-\mathrm{N}$ bond is shifted by $18 \mathrm{~cm}^{-1}$ in the P-Pd" $\left(1609 \mathrm{~cm}^{-1}\right)$ compared to that of the $\mathbf{P}$ alone. We can thus 
conclude to the effective formation of the coordination bonds. ${ }^{22}$ However, considering the weak change of the stretching bond value in P-IPhI (1589 $\left.\mathrm{cm}^{-1}\right)$, the halogen bonding is only suspected. Unfortunately, the hydrogen bond in P-TPA $\left(1591 \mathrm{~cm}^{-1}\right)$ could not be observed. There are two possible explanations for this absence of shift: first, the procedure to prepare the supramolecular structure may not be efficient and thus the expected interactions was not obtained. Second, the pedestal may naturally display hydrogen bonds between the pyridine unit and the methyl group of its $p$-xylene core. As a consequence, the pedestal alone could already present the signal of a hydrogen bonded pyridine. This second hypothesis would be in accordance with the negative shift for the halogen bond (weaker than the $\mathrm{H}$-bond) and the positive shift of the coordination bond (stronger than the $\mathrm{H}$-bond).

\subsection{Self-assembly of P on HOPG}

Scanning tunnelling microscopy (STM) was used to observe first the self-assembly of the pedestal $\mathbf{P}$ alone at the liquid/solid interface. Indeed, based on our previous works on Janus tectons, we expect that the arrangement of $C$ and JT would be similar on the same substrate, since in all known examples the lower-deck (pedestal, P) governs the final arrangement. This is the reason why we focused first on this model plannar tecton, which is more easily imaged by STM than its 3D derivatives. Experimentally, a solution of $\mathbf{P}$ in dichloromethane was prepared at a concentration of $10^{-3}$ mol. $\mathrm{L}^{-1}$ and deposited on the HOPG surface. As shown in Figure 7 (a), ordered 2D domains formed by the assembly of pedestal $\mathbf{P}$ were observed as bright more or less elongated patterns in a quasi-square lattice network with the unit cell dimensions $a=2.1 \pm 0.1 \mathrm{~nm}, b=2.2 \pm 0.1 \mathrm{~nm}$ and an angle $\alpha=94^{\circ} \pm 2^{\circ}$. Figure 7 (b) shows a first set of bright patterns that are nearly parallel to the fast-scan direction. A second set of less contrasted patterns are elongated in the direction perpendicular to the former (I.e. close to the slow scan direction). These patterns can be ascribed to a quasi-square molecular lattice with two nearly-perpendicular rod-shaped molecules per unit cell as illustrated in upper left corner of figure 7 (b). Larger-scale STM images show numerous domains oriented at approximately $0^{\circ}, \pm 30^{\circ}$, $\pm 60^{\circ}$ from each other, as illustrated in figure 7 (c). Following the principles of molecular epitaxy on HOPG, ${ }^{23}$ these data are consistent with the model approximately described in figure 7 (d) : One axis of the quasi-square lattice is close to a $<100>$ axis of HOPG surface whereas the other is close to the $\langle 110\rangle$ axis perpendicular to the former $<100>$ one. Notice that this relation with HOPG is preserved through a $30^{\circ}\left(\bmod .60^{\circ}\right)$ rotation of the molecular lattice, which explains the observed orientations between domains. Since the lattice is formed of two prochiral molecules in the same left- or righthanded configuration, the lattice itself is pro-chiral, and becomes chiral by considering the vertical axis orientation due to the substrate surface. ${ }^{24}$ One thus expect the existence of mirror symmetric domains forming angles of $\pm \theta$ with HOPG $<100>$ axis. ${ }^{23}$ From STM image and molecular model [figure 7 (c-d) ] it appears that $\theta$ is small, i.e. of the order of $2^{\circ}$. It nevertheless explains the small variations of domain-to-domain angles with respect to the $0^{\circ}, \pm 30^{\circ}, \pm 60^{\circ}$ rule. The above mentionned difference in contrast between the two molecules in the unit cell can be explained by the difference of relations between molecule and HOPG conjugated orbitals which is known to strongly influence the electron density of states. ${ }^{25} \mathrm{An}$ influence of tip shape cannot be ruled out, and can also contribute to this differential contrast and more specifically to the different patterns presented by the same molecules with different orientations.

Considering the organised system absorbed on the surface, the network seems to be driven by hydrogen bonds between the pyridine units and the methyl groups on the core of the molecule. This is consistent with the principles of interactions between adsorbed molecules with pyridyl and alkyl terminations. ${ }^{15}$ Such pyridyl-driven assemblies has been observed for molecules bearing two ${ }^{26-28}$ but also three ${ }^{29-31}$ and even four pyridine entities ${ }^{32}$. The proposed scheme [figure 7 (d) ] is fully consistent with the assembly of short bivalent pyridyl-terminated rod-shaped molecules [FC5]. Notice however, that longer molecules could lead to structures with parallel molecules in order to improve the coverage. ${ }^{27}$ The observation that the same molecular arrangement can align either on $a<100>$ or $<110>$ direction of HOPG shows the poor influence of the substrate on the organization. This is further substantiated by the above cited literature which shows that the same self-assembling principles apply for various substrates as dissimilar as Au and HOPG. This self-assembly thus appears to be driven by intrinsic intermolecular interactions, which doesn't need assistance of the substrate in contrast with alkyl-chain based assembly.
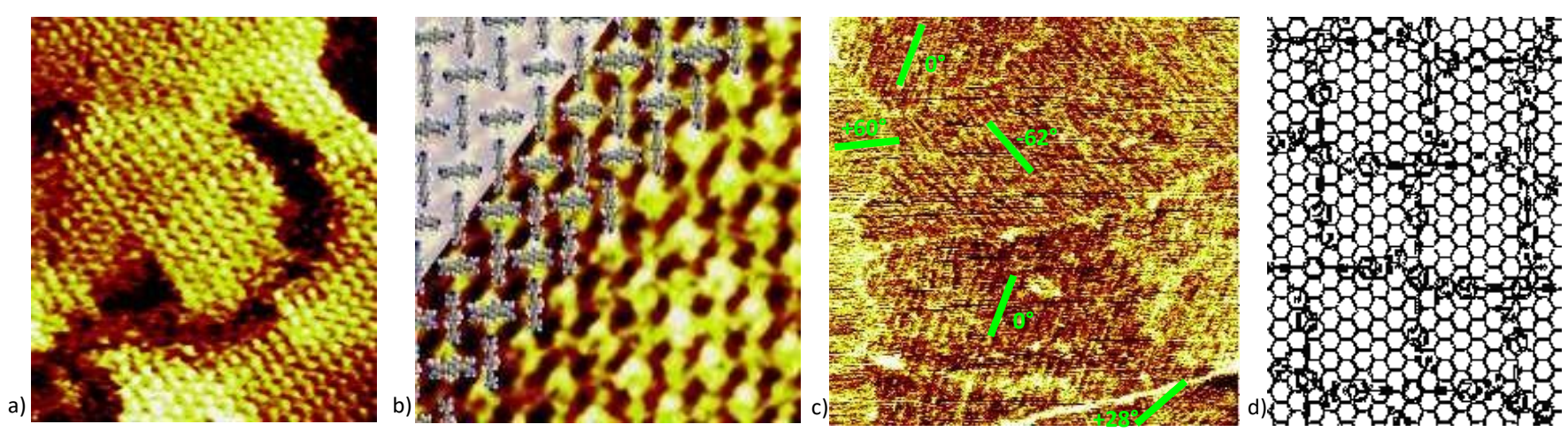

Figure 7: STM images of the self-assembled monolayer of $\mathbf{P}\left(\mathrm{a}, \mathrm{I}=35 \mathrm{pA}, \mathrm{U}_{\text {bias }}=630 \mathrm{mV}, 50 \times 50 \mathrm{~nm}\right)$, with overlaid molecular models (b, $10 \times 10 \mathrm{~nm}$ ) large scale $(\mathrm{c}, 110 \mathrm{~nm})$ showing different domain orientations (light green) and the molecular model on a HOPG layer (d). 


\section{Conclusions}

We designed and synthesised new molecular architectures based on the 3D Janus tecton concept that can be suitable for surface selfassembly by supramolecular interactions such as ionic, coordination, halogen or hydrogen bonding. These non-covalent interactions were studied by $\mathrm{pH}$-dependent absorption and emission measurements, and by infra-red spectrometry which proved that both ionic and coordination bonding are compatible with the molecules' design. Finally, the supramolecular self-assembly of the pedestal $\mathbf{P}$ was studied on HOPG at the liquid/solid interface. The arrangement of the molecules on HOPG show a quasi-square lattice formed by hydrogen bonding between the pyridine unit and the methyl groups on the $p$-xylene core. The quasi-square lattice indicates strong intermolecular interactions are present between the $\mathbf{P}$ molecules leading to a supramolecular self-assembly which is independent of the underlying HOPG structure. As perspectives, such different interactions being able to favour or modify the supramolecular selfassembly of $\mathbf{P}$ (respectively $\mathbf{C}, \mathbf{J T}$ ) at the liquid/solid interface, additional experiments will be performed in a near future to study their different supramolecular self-assemblies with other substrates.

\section{Conflicts of interest}

There are no conflicts to declare.

\section{Acknowledgementsr}

This research was supported by a PhD grant overseen by the French government (Ministry of Education and Research).

\section{Notes and references}

${ }^{1}$ J.V. Barth, G. Costantini and K. Kern, Nature 2005, 437, 671-679. ${ }^{2}$ S. De Feyter and F.C. De Schryver. J. Phys. Chem. B, 2005, 109, 42904302.

${ }^{3}$ D.P. Goronzy, M. Ebrahimi, F. Rosei,A.Y. Fang, S. De Feyter, S.L. Tait, C. Wang, P.H. Beton, A.T.S. Wee, P.S. Weiss and D.F. Perepichka, ACS Nano 2018, 12, 7445-7481.

${ }^{4}$ S. Xu, Q. Zeng, J. Lu, C. Wang, L. Wan and C.L. Bai, Surf. Sci. 2003, 538, L451-L459; D. Bléger, D. Kreher, F. Mathevet, A-J. Attias, G. Schull, A. Huard, L. Douillard, C. Fiorini-Debuischert and F. Charra, Angew. Chemie - Int. Ed. 2007, 46, 7404-7407; G. Schull, L. Douillard, C. Fiorini-Debuisschert, F. Charra, F. Mathevet, D. Kreher and A-J. Attias, J. Nano Lett. 2006, 6, 1360-1363.

${ }^{5}$ M.E. Stawasz, D.L. Sampson and B.A. Parkinson, Langmuir 2000, 16 2326-2342.

${ }^{6}$ G. Velpula, M. Li, Y. Hu, Y. Zagranyarski, W. Pisula, K. Muellen, K.S. Mali and S. De Feyter, Chem. Eur. J. 2018, 24, 12071 - 12077 ; O.D. Arado, M. Luft, H. Mönig, P.A. Held, A.; Studer, S. Amirjalayer and H. Fuchs, Phys. Chem. Chem. Phys. 2016, 18, 27390-27395; S. Stepanow, T. Strunskus, M. Lingenfelder, A. Dmitriev, H. Spillmann, N. Lin, J.V. Barth, C. Wöll and K. Kern, J. Phys. Chem. B 2004, 108, 19392-19397; M. Ruiz-Osés, T. Kampen, N. González-Lakunza, I. Silanes, P.M. Schmidt-Weber, A. Gourdon, A. Arnau, K. Horn and J.E. Ortega, ChemPhysChem 2007, 8, 1722-1726.

${ }^{7}$ K-H. Chung, J. Park, K.Y. Kim, J.K. Yoon, H. Kim, S. Han and S.J. Kahng, Chem. Commun. 2011, 47, 11492-11494; R. Gutzler, H. Walch, G. Eder, S. Kloft, W.M. Heckl and M. Lackinger, Chem. Commun. 2009,
29, 4456-4458; J.C. Russell, M.O. Blunt, J.M. Garfitt, D.J. Scurr, M. Alexander, N.R. Champness and P.H. Beton, J. Am. Chem. Soc. 2011, 133, 4220-4223.

${ }^{8}$ B. Song, S. Kandapal, J. Gu, K. Zhang, A. Reese, Y. Ying, L. Wang, H. Wang, Y. Li, M. Wang, S. Lu, X-Q. Hao, X. Li, B. Xu and X. Li, Nat. Comm. 2018, 9, 4575 ; N. Lin, A. Langner, S.L. Tait, C. Rajadurai, M. Ruben and K. Kern, Chem. Commun. 2007, 1, 4860-4862; M.A. Lingenfelder, H. Spillmann, A. Dmitriev, S. Stepanow, N. Lin, J.V. Barth and K. Kern, Chem. - A Eur. J. 2004, 10, 1913-1919; S. Stepanow, M. Lingenfelder, A. Dmitriev, H. Spillmann, E. Delvigne, N. Lin, X. Deng, C. Cai, J.V. Barth and K. Kern, Nat. Mater. 2004, 3, 229-233.

${ }^{9}$ L. Sosa-Vargas, E. Kim and A-J. Attias, Mater. Horiz., 2017, 4, 570; K. Ariga, M. Nishikawa, T. Mori, J. Takeya, L.K. Shrestha and J.P. Hill, Sci. Tech. Adv. Mater. 2019, 20:1, 51-95.

10 Z.C. Dong, X.L. Zhang, H.Y. Gao, Y. Luo, C. Zhang, L.G. Chen, R. Zhang, X. Tao, Y. Zhang, J.L. Yang and J.G. Hou, Nat. Photonics 2010, 4, 50-54.

${ }^{11}$ X.H. Qiu, Science 2003, 299, 542-546; J. Repp, G. Meyer, S.M. Stojković, A. Gourdon and C. Joachim, Phys. Rev. Lett. 2005, 94, 26803.

12 J.A. Mann, J. Rodríguez-López, H.D. Abruña and W.R. Dichtel, J. Am. Chem. Soc. 2011, 133, 17614-17617.

${ }^{13}$ P. Du, M. Jaouen, A. Bocheux, C. Bourgogne, Z. Han, V. Bouchiat, D. Kreher, F. Mathevet, C. Fiorini-Debuisschert, F. Charra and A-J. Attias, Angew. Chemie Int. Ed. 2014, 5, 10060-10066.

${ }^{14}$ S. Le Liepvre, P. Du, D. Kreher, F. Mathevet, A-J. Attias, C. FioriniDebuisschert, L. Douillard and F. Charra, ACS Photonics 2016, 3, 2291-2296.

${ }^{15}$ X. K. Li, S. Q. Zhang, J. Q. Li, Y. X. Qian, W. B. Duan and Q. D. Zeng, New Journal of Chemistry, 2019, 43, 13315-13325

${ }^{16} \mathrm{~S}$. Takahashi, Y. Kuroyama, K. Sonogashira and N. Hagihara, Synthesis (Stuttg). 1980, 627-630.

${ }^{17}$ L. A. Carpino and A.C. Sau, J. Chem. Soc., Chem. Commun. 1979, 11, 514-515.

${ }^{18}$ K. Sonogashira, Y. Tohda and N. Hagihara, Tetrahedron Lett. 1975, 16, 4467-4470.

${ }^{19}$ C. Djerassi, Chem. Rev. 1948, 43, 271-317.

${ }^{20}$ H.R. Hudson, R.R.F. Kinghorn and W.S. Murphy, J. Chem. Soc. C. 1971, 3593-3596.

${ }^{21}$ G.W. Stacy, A.J. Papa, F.W. Villaescusa and S.C. Ray, J. Org. Chem. 1964, 29 (3), 607-612.

${ }^{22}$ I.S. Perelygin and M.A. Klimchuk, J. Appl. Spectrosc. 1976, 24 (1), 43-46.

${ }^{23}$ D. Bleger, D. Kreher, F. Mathevet, A. J. Attias, I. Arfaoui, G. Metge, L. Douillard, C. Fiorini-Debuisschert and F. Charra, Angewandte Chemie-International Edition, 2008, 47, 8412-8415.

${ }^{24} \mathrm{~N}$. Katsonis, E. Lacaze and B. L. Feringa, Journal of Materials Chemistry, 2008, 18, 2065-2073.

${ }^{25}$ N. Kalashnyk, M. Jaouen, C. Fiorini-Debuisschert, L. Douillard, A. J. Attias and F. Charra, Chemical Communications, 2018, 54, 9607-9610. ${ }^{26}$ M. A. Dubois, O. Guillermet, S. Gauthier, G. Zhan, Y. Makoudi, F. Palmino, X. Bouju and A. Rochefort, Physical Chemistry Chemical Physics, 2018, 20, 15350-15357.

27 D. Hotger, P. Carro, R. Gutzler, B. Wurster, R. Chandrasekar, S. Klyatskaya, M. Ruben, R. C. Salvarezza, K. Kern and D. Grumelli, Physical Chemistry Chemical Physics, 2018, 20, 15960-15969.

${ }^{28}$ M. El Garah, A. Ciesielski, N. Marets, V. Bulach, M. W. Hosseini and P. Samori, Chemical Communications, 2014, 50, 12250-12253.

${ }^{29}$ A. Mukherjee, J. Teyssandier, G. Hennrich, S. De Feyter and K. S. Mali, Chemical Science, 2017, 8, 3759-3769. 
${ }^{30}$ T. R. Umbach, M. Bernien, C. F. Hermanns, L. L. Sun, H. Mohrmann, K. E. Hermann, A. Kruger, N. Krane, Z. Yang, F. Nickel, Y. M. Chang, K. J. Franke, J. I. Pascual and W. Kuch, Physical Review B, 2014, 89, 235409.

${ }^{31}$ A. Ciesielski, P. J. Szabelski, W. Rzysko, A. Cadeddu, T. R. Cook, P. J. Stang and P. Samori, Journal of the American Chemical Society, 2013, 135, 6942-6950.

${ }^{32}$ A. Stein, D. Rolf, C. Lotze, C. Czekelius, K. J. Franke and P. Tegeder, Journal of Physics-Condensed Matter, 2019, 31, 044002. 